\title{
INNOVATIVE METHODS IN THE TEACHING LEARNING PROCESS OF BASIC SCIENCES
}

\author{
*Nagaveni B. \& M. Prem D'Souza
}

\section{Introduction}

"The aim of education should be to teach the child to think, not what to think" John Dewey.

"The classroom is now a vital struggle for survival with the immensely persuasive 'outside world' created by new informational media. Education must shift from instruction, from imposing of stencils, to discovery - to probing and exploration and to the recognition of the language of forms." - Herbert Marshall McLuhan.

Realizing the tremendous responsibility of higher education towards the learner, the feacher creates a conducive climate to learning. The environment nurtures the learning behavior in a more permanent way when it is learner centered. Each subject has its intrinsic value and no one can. say we do not use basic sciences in our day to day living. Biology teaches us many lessons in physiology, biochemistry, heredity and evolution, which need to be remembered beyond the classroom and the examination hall.

* S.G.L. Dept. of Zoology, St. Agnes College, Bendore, Mangalore - 575002 
Psychologically it is beneficial to the teacher and the taught when both enjoy what they are doing and accept the situation in a more mature responsible way.

The decrease in number among those who opt for Basic Sciences, indifference among those who come, the discouragement by peers of retaining pure sciences in the curriculum, as well as introspection by the staffled to a new pattern of thinking in Teaching and Learning process.

Innovations in the feaching learning process are necessary if Basic Sciences have to remain in our colleges and universities. Towards such progress a few methods were adopted and tried. Each of them proved to be a springboard to success.

The following study has kept the above considerations in mind.

\section{Methodology}

Five types of innovative programs chosen were:

1. Seminars by Choice - Learners gain confidence and develop teaching skills.

2. Project Work - on Biodiversity studies of various animal groups, Vermitechnology, Fish/Shrimp Culture, Dairy, Poultry, and Sericulture etc. Project work involved visits for field study, preparation of field report with photographs, pictures and newspaper clippings on the subject. In this connection two students got an opportunity to present a paper at a National Seminar on Biodiversity held at Kottayam, Kerala in January 2004.

3. Open-ended Experimentation: An interdisciplinary programme to arouse curiosity in the learner for experimentation.

4. ICT Module - To make a study of the selected topic and to prepare a powerpoint presentation. This is a useful tool in teaching and research. With the aid of this presentation students learn to gather information using the media and technology. This provides for self-learning. Some of the modules already completed are 'Know your Body', 'Know your Environment', 'Modern concepts in Molecular Biology', 'Genetics' and 'Wild Life Biology'.

5. Notice Board or Wall Magazine Contest - Learners choose information from the mass media and creatively learn to display. 


\section{Quality Sustenance in the Study of Basic Sciences}

Ten students were selected for this study from each category. The students were given an overview of the study at the beginning of the term. They were allowed to work at their own pace within the framework of the curriculum. The students were observed regularly with regard to attendance, contribution of ideas, and interaction with peers/teachers. Individual effort and teamwork was assessed.

Type I - Extended to eight months of the academic year. However, a student who was ready with her presentation could do so before time. This gave the learner the ability to decide and act.

Type II - This extended to six months. The students were prepared for fieldwork with sufficient input. Three to five members formed a team. They prepared schedule of work with regard to field visits, collection of specimens and their identification. Data Sheet Format and preferred timings of field visits were also drawn up. Learning was a contractual experience.

Type III - had an interdisciplinary approach. The problems were posed to the students and different ways / procedures were discussed. The students then offered solutions that would best address these problems. Regular guided library work helped the students to conduct experiments at the end of four months and prepare a report on their findings. Examples: Micrometry, Dermatoglyphics, Morphological evidences in evolution (serial analogy).

Jype IV - Duration 6-8 months. Computer knowledge was a prerequisite. In the beginning one-day's hands on experience in the power point was given to each batch. The students then selected a topic for study, collected information form the Internet, books, journals and magazines. After sufficient research they prepared an ICT Module with power point. Individually, they were prepared for their presentations. Learning was highly motivated and enioyable.

Type V - Duration 6-8 months. A team of two or three students chose a topic and date for display. The display had to satisfy the following criteria: current news or information, technology development, applications and relevance of the topic. A quiz was announced for the participants at the end of the term for sustained interest in one another's work.

We have put Zoology and other Basic Sciences in focus in this study, which extended from 2001-2004. Basic Sciences are not unwanted options but the first choice for scientifically oriented students. Relevance of the subject in terms of Entrepreneurship, societal and community needs, Healthy living, Eugenics, Economic Zoology, 
Knowledge of the Environment etc. cannot be undermined. Pure sciences provide the knowledge and a forum to understand basic concepts of Nature.

Staff of Zoology Department was transformed to take up research by way of minor research project and present papers. This benefited the department in the preparation and compilation of learning resources like C.Ds, project books, lists and picture files.

\section{Discussion}

The study shows that a motivated learner performs better. In realizing the objective of our study we found that learning took place in all the three domains like cognitive, affective and psychomotor (Bloom's Taxonomy). The students were motivated to go to the higher realms of educational objectives of analyzing, comparing and evaluating the data that they had collected in the process of education. These programmes of study were value based. The learners went through stages of value development in terms of choosing the best from an array of options. Compassion and conservation of fauna and environment led them to value Life Sciences with sustained interest.

\section{Results}

\section{Comparative display of Scores in the Terminal Exams and Innovative Programmes 2001-2004} Table 1.*

\begin{tabular}{|c|c|c|c|c|c|c|c|c|}
\hline \multirow{2}{*}{$\begin{array}{l}\text { Sl. } \\
\text { No. }\end{array}$} & \multicolumn{2}{|c|}{$\begin{array}{l}\text { Seminars by Choice } \\
\text { - Type I - } 2004\end{array}$} & \multicolumn{2}{|c|}{$\begin{array}{l}\text { Field Study Project } \\
\text { - Type II - } 2002\end{array}$} & \multicolumn{2}{|c|}{$\begin{array}{c}\text { Open Ended } \\
\text { Experimentation } \\
\text { - Type III - 2002 }\end{array}$} & \multicolumn{2}{|c|}{$\begin{array}{l}\text { Notice Board/Wall } \\
\text { Magazine- } \\
\text { Type V-2004 }\end{array}$} \\
\hline & $\begin{array}{l}\text { Terminal } \\
\text { Exam. }\end{array}$ & $\begin{array}{l}\text { Innovative } \\
\text { Programme }\end{array}$ & $\begin{array}{c}\text { Terminal } \\
\text { Exam. }\end{array}$ & $\begin{array}{l}\text { Innovative } \\
\text { Programme }\end{array}$ & $\begin{array}{l}\text { Terminal } \\
\text { Exam. }\end{array}$ & $\begin{array}{l}\text { Innovative } \\
\text { Programme }\end{array}$ & $\begin{array}{l}\text { Terminal } \\
\text { Exam. }\end{array}$ & $\begin{array}{l}\text { Innovative } \\
\text { Programme }\end{array}$ \\
\hline 1. & 48 & 65 & 60 & 78 & 62 & 78 & 68 & 80 \\
\hline 2. & 48 & 85 & 58 & 74 & 70 & 79 & 50 & 65 \\
\hline 3. & 10 & 75 & 46 & 77 & 60 & 81 & 78 & 75 \\
\hline 4. & 42 & 65 & 44 & 78 & 84 & 75 & 20 & 65 \\
\hline 5. & 48 & 70 & 56 & 80 & 88 & 81 & 64 & 95 \\
\hline 6. & 35 & 60 & 72 & 64 & 88 & 68 & 54 & 65 \\
\hline 7. & 76 & 85 & 55 & 84 & 48 & 70 & 46 & 50 \\
\hline 8. & 35 & 80 & 63 & 92 & 65 & 72 & 42 & 65 \\
\hline 9. & 36 & 85 & 28 & 76 & 58 & 78 & 81 & 60 \\
\hline 10. & 56 & 90 & 46 & 84 & - & - & 57 & 40 \\
\hline
\end{tabular}

*Percentile Scores 
Table 2.*

\begin{tabular}{|c|c|c|c|c|c|c|}
\hline \multirow{2}{*}{$\begin{array}{c}\text { Serial } \\
\text { No. of } \\
\text { students }\end{array}$} & \multicolumn{2}{|c|}{$\begin{array}{c}\text { ICT Module } \\
\text { Know your Body } \\
\text { Type IV - 2002 }\end{array}$} & $\begin{array}{c}\text { ICT Module } \\
\text { Know Your Environment } \\
\text { Type IV - 2003 }\end{array}$ & \multicolumn{2}{|c|}{$\begin{array}{c}\text { ICT Module } \\
\text { Molecular Biology } \\
\text { Type IV - 2004 }\end{array}$} \\
\cline { 2 - 7 } & $\begin{array}{c}\text { Terminal } \\
\text { Exam. }\end{array}$ & $\begin{array}{c}\text { Innovative } \\
\text { Programme }\end{array}$ & $\begin{array}{c}\text { Terminal } \\
\text { Exam. }\end{array}$ & $\begin{array}{c}\text { Innovative } \\
\text { Programme }\end{array}$ & $\begin{array}{c}\text { Terminal } \\
\text { Exam. }\end{array}$ & $\begin{array}{c}\text { Innovative } \\
\text { Programme }\end{array}$ \\
\hline 1. & 48 & 82 & 64 & 78 & 80 & 70 \\
\hline 2. & 86 & 83 & 88 & 91 & 84 & 81 \\
\hline 3. & 84 & 82 & 78 & 81 & 42 & 78 \\
\hline 4. & 46 & 84 & 76 & 81 & 56 & 67 \\
\hline 5. & 84 & 86 & 68 & 77 & 83 & 87 \\
\hline 6. & 84 & 85 & 92 & 85 & 72 & 80 \\
\hline 7. & 40 & 88 & 75 & 88 & 90 & 69 \\
\hline 8. & 24 & 78 & 59 & 78 & 54 & 82 \\
\hline 9. & 14 & 75 & 74 & 81 & 82 & 89 \\
\hline 10. & 46 & 82 & 54 & 74 & 90 & 83 \\
\hline
\end{tabular}

* Percentile Scores

\section{Conclusion}

Rabindranath Tagore did not want education to be shut off from the daily life of the people. He said, "The highest mission of education is to help us to realize the inner principle of the unity of all knowledge and all the activities of our social and spiritual being."

\section{References}

- Benjamin Bloom's Taxonomy of Educational Objectives.

- Fennimore T.F. and Tinzmann M.B., NCREL, Old Brook, 1990.

- Mehrens and Lehmann, Clinical Psychology Publishing Company, Inc., 1973.

- New Life World Incorporated, "Interactive Learning Model", Orlando, Florida, U.S.A., 1995.

- Taneja V.R., Educational Thought and Practice, published by Sterling Publishers Pvt. Ltd., New Delhi, 1973. 